\title{
THE PASSENGER PIGEON
}

\section{IN SASKATCHEWAN}

\section{by C. Stuart Houston, 863 University Drive, Saskatoon}

It is a surprising but not always appreciated fact that, for much of the last century, Carlton House and Cumberland House were better known ornithologically than most other areas on this continent, and probably better than any other area in Canada. Fauna Boreali-Americana, Volume 2 the Birds (Swainson and Richardson, 1832), describing the collections and abservations of Richardson and Drummond, in the 1820 's, largely at these two localities, antedated by 60 years the publication of McIlwraith's Birds of Ontario. The studies by another serious observer, Thomas Blakiston (1861-63), who lived at Carlton in 1857-58, antedated McIlwraith by 25 years.

It is regrettable that Richardson, Drummond and Blakiston left us so little solid information about the two species which later disappeared-the Passenger Pigeon (Ectopistes migratorius) and the Eskimo Curlew (Numenius borealis). The explanation is quite simple-these two species were so common as to merit little comment, much less any attempt to collect specimens. The situation might be compared to one of us visiting another city today, and recording little or nothing about the status of the nowubiquitous House Sparrow.

The classic, scholarly study of the Passenger Pigeon by Schorger (1955) omitted some important observations of this species within the present boundaries of Saskatchewan. Several publications were not available to Schorger and in several others the geographical references were unclear and misinterpreted. I have collected 21 observations of the Passenger Pigeon within Saskatchewan and two within immediately adjacent portions of Manitoba. These are listed below in chronological order.

\section{PASSENGER PIGEON RECORDS FOR SASKATCHEWAN AND ADJACENT MANITOBA}

July 24, 1691. [Nipawin]. Henry Kelsey (1929). “ . . . we sat down \& roasted 3 pigeons wch I had kill'd yt morning."

Whillans' (1955) detailed and plausible reconstruction of Kelsey's route, presuming Kelsey had ascended the Saskatchewan, would place this a few miles south of the present site of Nipawin. Alternatively, if Kelsey had ascended the Carrot River, as Bell suggested (1928), he would have been a bit further south, somewhere east of the present sites of Carrot River or Arborfield.

1774-1775. [Cumberland House]. Samuel Hearne (1795). "In the interior parts of the country they fly in large flocks, and perch on the poplar trees in such numbers that I have seen twelve of them killed at one shot. They usually feed on poplar buds, and are good eating, though seldom fat. They build their nests in trees, the same as the Wood Pigeons do; never lay but two eggs, and are very scarce near the sea-coast in the Northern parts of Hudson's Bay."

The only inland site where Hearne lived for any time was Cumberland House, which he founded September 3, 1774 and where he resided until May 29, 1775 and again from August 19 to October 16, 1775.

1800 - 1802. Assiniboine and Swan Rivers. Daniel W. Harmon (1820). "May 2 [1802] ... of fowls, we have swans, geese, bustards [Canada Geese], cranes, cormorants, loons, snipes, several species of ducks, water-hens [Coots], pigeons, partridges [Ruffed Grouse], pheasants [sharp-tailed Grouse], \&c. \&c." 
Harmon resided at Alexandria, a North West Company trading post on the Assiniboine River, 10 miles north and two miles east of the present site of Canora, Saskatchewan, from October 23, 1800 to March 6, 1801 and from June 1 to October 2, 1801. He then moved to Thunderbird Mountain post, named for the nearby Thunder Hill, on October 2, 1801. This post was on the Swan River, seven miles north of the present site of Durban, Manitoba and six miles west of the the present Saskatchewan boundary. His observations undoubtedly refer to the Upper Assiniboine and the entire Swan River valley.

August, 23, 1808. Saskatchewan River, east of The Pas, Manitoba. Alexander Henry (the younger). (1897). "We shot a number of wild fowl during the day-outardes [Canada Geese], ducks, pelicans, and some pigeons, of which we saw great numbers."

Owing to mention of a "pine island", Schorger erred in assigning latitude and longitude to this observation; it was one day's paddle east of The Pas, between $59^{\circ} 30^{\prime}$ and $53^{\circ} 50^{\prime}$ North and between $100^{\circ} 30^{\prime}$ and $101^{\circ}$ West.

October 23, 1819 - June 13, 1820. [Cumberland House]. Robert Hood and John Richardson (compiled by Sabine, in Franklin, 1823). "They breed together in large numbers, rearing only one young at a time ... though they prefer living thus in common, they are frequently known to make their nests in detached places ... It seems likely that, as population and cultivation extend westward, the countless multitudes of these birds, which darken the air for hours and miles together in their flight, will be reduced; their visitations must be ruinous to agricultural districts, and consequently incompatible with civilization; indeed, it is probable that their less frequent appearance in the Atlantic States has been caused by the necessity they have felt to retire from the frequented abodes of man."

A specimen was sent back from the first Franklin expedition, most likely from Cumberland House, where "the principal supply of specimens was obtained" collected by John Richardson or Robert Hood. Joseph Sabine, in the zoological appendix to the account of that expedition, quoted several facts from Alexander Wilson, but Sabine's prophecy of the ultimate decline in numbers of the Passenger Pigeon was apparently original.

July 29, 1820. Ile-à-la-Crosse. Robert Hood (in Franklin, 1823). "The only birds visible at this season, are common to every part of the Missinnippi [Churchill River]: gulls, ducks, pigeons, goatsuckers and the raven

June 28 - August 20, 1825. Cumberland House. Thomas Drummond (1830). "The Passenger Pigeon is very common, building its nest in the willow bushes on the margins of the lake, and feeding principally at this season upon the berries of the Cornus alba [red osier dogwood] and C. Canadensis [bunchberry]."

This is the only nesting record for the present province of Saskatchewan, and the farthest northwest for the continent.

May through July 14, 1827. Carlton. Thomas Drummond. May 24 - June 21, 1827. Cumberland House, John Richardson (Swainson and Richardson, 1832). "Summer. In small flocks ... arrives in the fur-countries in the latter end of May and departs in October. It annually attains the sixtysecond degree of latitude [Great Slave Lake] in the warmer central districts, but reaches the fifty-eighth parallel on the coast of Hudson Bay [north of York Factory] in very fine summers only. . . . A few hordes of Indians, that frequent the low,flooded tracts at the south end of Lake Winnipeg, subsist principally on the pigeons during a period of the summer when the sturgeon-fishery is unproductive, and the Zizania aquatica [wild rice] has not yet ripened; but farther north, these birds are too few in number to furnish a material article of diet."

July 25, 1828. Saskatchewan River, eight miles east of Manitoba boundary. 
Archibald McDonald and George Simpson (McDonald, 1872). "Put up about two leagues below the Barriere... Shot three or four pigeons."

July 6, 1833. Sturgeon Landing on Namew Lake. Richard King (1836). "... and encamped at the mouth of Sturgeon River. While the men were occupied in pitching our tents and pre. paring the supper, Mr. Annance and myself took a stroll through the woods in pursuit of some pigeons that had been seen to alight. Although we got no pigeons ..."

July 14 - August 8, 1835. Churchill, Sturgeon - Weir and Saskatchewan rivers from La Loche to Grand Rapids. Richard King (1836). "Along the whole course of the Missinnippi [Churchill] and Saskatchewine Rivers, we met with small flocks of the Columba migratoria, or passenger pigeon, and here [Grand Rapids, Manitoba] they were extremely numerous."

May 23, 1858. Carlton. Thomas W. Blakiston (1862-63). "Common in the interior. The first Passenger Pigeon arrived at Fort Carlton in 1858, on the 23rd day of May; and by the middle of June numerous flocks were making their way northwards. They may be distinguished at a long distance, from waterfowl or waders, by their flight being in no particular order, but on the principle of 'everyone for himself, and the devil take the hindermost'."

July 20-26, 1858. Qu'Appelle River, Fort Qu'Appelle to Fort Ellice. J. A. Dickinson (Chapter 17 in Hind, 1860). "Cherry-birds [Cedar Waxwings] and pigeons were calmly and listlessly perched on the dense trees, having eaten plentifully of their favourite fruits ..."

August 2-5, 1858. South Saskatchewan River, Elbow to east of St. Louis. Henry Youle Hind (1860). “ ... extraordinary absence of animal life ... we have seen ... of birds, eagles, geese, a few ducks, kingfishers, cliff martins, pigeons, crows, cranes, plover, hawks, and a few of the smaller birds..."

June, 1972
The likely sites for the pigeon sightings were the Moose Woods, south of the present site of Saskatoon, and the area from St. Laurent to the forks east of St. Louis.

July 2, 1859. East of Fort Qu'Appelle. James Carnegie, Earl of Southesk (1875). "M'Kay, however, discovered a few pigeons in a little grove, and shot two or three of them. We halted for dinner not far from Qu'Appelle Fort."

July 25 - Sept. 12 - October 22, 1873. Winnipeg to Rocky Mountain House to Grand Rapids. Alfred R. C. Selwyn (1875). "Cranes, bitterns, plovers, sand-pipers, snipe and other waders, as well as pigeons, blackbirds, larks and a number of other small birds are plentiful on the prairies or in the swamps, or along the river valleys, and crows and several kinds of hawks are also very common."

Autumn, 1874. Fort Pelly on the Assiniboine. Charles A. Boultbee (in (Atkinson, 1905). "I have resided in Manitoba since 1872 and have taken pigeons as far north as Fort Pelly in the fall of $1874 \ldots$..."

Mid - May,.. 1877... Whitesand.. River [northwest of Kamsack]. W. J. McLean (in Atkinson, 1905). "1877 was the last occasion on which I saw any numbers of the birds, when I encountered large flocks of them passing northwesterly from White Sand River near Fort Pelly. This was on a dull drizzling day about the middle of May, and I presume they were then heading toward the Barren grounds district, where the blueberry and cranberry are again very abundant."

August-September 1881. Swan River [Parrhill Lake to Livingstone]. John Macoun (1909). "In the latter part of August and early in September of the same year (1881), on the Swan River, above Livingstone, and also on the upper Assiniboine we saw large flocks and as food was scarce we shot large numbers for the pot. The low flats along the river were covered with Cornus stolonifera [red osier dogwood], and on the ripe berries of this shrub they were feeding." 
September, 1881. Assiniboine River, below Fort Pelly [near Kamsack]. John Macoun (1922). "One afternoon, the canoe was ahead of my boat... I heard a shot ... my nephew, Davie ... was sitting on a box in the canoe, and fired at the pigeons in the tree, and the recoil of the gun caused him to lose his balance and he tumbled headlong into the river..."

"In all my travels in the northwest I have never since found them breeding" (in Thompson, 1890). "Few pigeons are seen on the plains, but in the latter part of August and the first half of September, they are abundant in the northern river valleys, feeding on the berries of the Wild Cornel" (Macoun, 1882).
1880 - 1885. Fort Qu'Appelle. George F. Guernsey. (in Thompson, 1891). "Occasional, [arrives] May 10."

October 10-18, 1883 and June 7-22, 1884. Homestead, sec. 36-28-1-W1, $11 / 2$ miles southwest of present Runnymede. Ernest E. Thompson (1886). "Common summer resident . . . noted along the Assiniboine."

1894-1900 Prince Albert and St. Louis. Eugene Coubeaux (1900). "Common; a straggler during the migrating season, and oftenest seen in fall."

Common was almost certainly an exaggeration, even for 1894 when Coubeaux arrived.

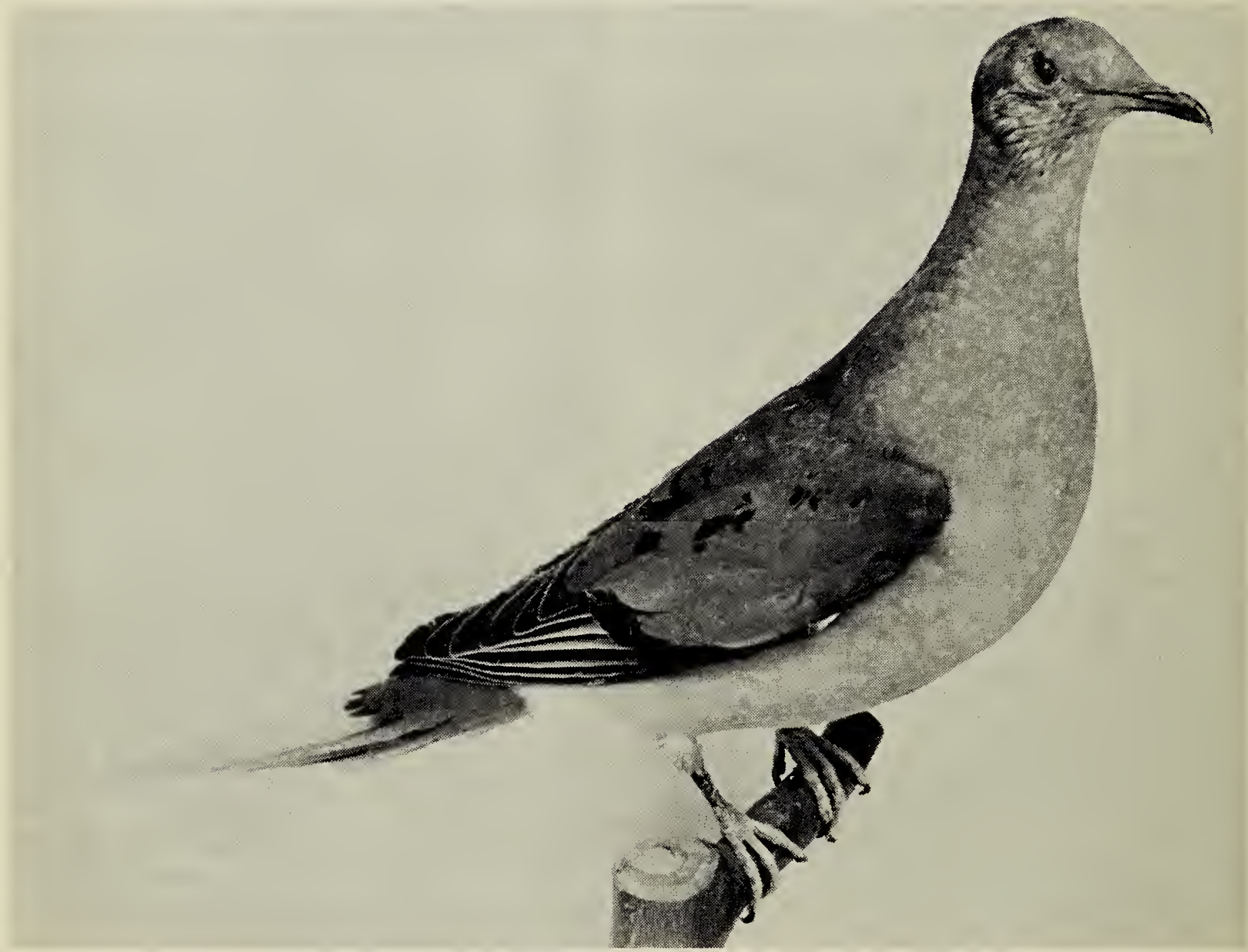

Photo by John Waddington, University of Saskatchewan

The only Passenger Pigeon specimen in Saskatchewan is the one shown above in the Department of Biology museum, University of Saskatchewan, Saskatoon Campus. It was not collected in Saskatchewan, however, but near Port Hope or Cobourg, Ontario in the 1800's by either Alexander Hamilton Pringle (who settled there in 1832-33) or by his son Alexander Whyte Pringle. It became the property of the grandson Ernest H. Pringle who came West in 1905 at the age of 17 years, and it was donated to the University by the latter's wife, Mrs. Eva Pringle of Saskatoon. 


\section{Discussion}

This single species may have accounted for up to one-half of the total number of individual birds on this continent; Schorger has estimated a possible Passenger Pigeon population of $3,000,000,000$ in the 1600 's. They declined slowly everywhere throughout the 1800's, with the decline becoming precipitous from 1871 to 1880 ; by 1890 they were rare everywhere. Human persecution, well documented by Schorger, was no doubt the main cause of their decline in their areas of greatest density, including Michigan and Wisconsin. Possibly other unknown factors were involved in their disappearance from the unsettled portions of Manitoba and Saskatchewan.

Spectacular flights occurred in neighboring Manitoba. In 1887 , Donald Murray related to Miller Christy how he "used to see flocks of pigeons following the course of the Red River, which were so large that the front of each flock was out of sight in the north whilst the tail was out of sight in the south, but they never come now" (Thompson, 1890).

Even in neighboring Alberta, farther from their centre of abundance, Alexander Henry the younger (1897) reported on August 31, 1810, a heavy southward migration "in immense flocks, particularly in the morning and evening." This was at Terre Blanche House, near the junction of the White Earth River with the North Saskatchewan, 12 miles E.S.E. of the present town of Smoky Lake, Alberta. Smith and Kidd (1971) have recently reported 14 bones from at least two individual Passenger Pigeons, in excavating the cellars of Fort George on the north bank of the North Saskatchewan, 30 miles west of the present Saskatchewan boundary; this fort was occupied from 1792 until about 1801.

The last breeding record for Manitoba was a colony of less than 20 nests on the west bank of the Waterhen River between Lake Manitoba and Lake Winnipegosis; John Macoun collected two eggs from the flimsy nests, some only 10 feet from the ground, on June 23, 1881. (Macoun and Macoun, 1909). The last specimen taken in the Winnipeg area was shot southeast of the St. Boniface cathedral in the fall of 1893 by Dan Smith, while the last Manitoba specimen, a magnificent male, was shot at Winnipegosis on April 10 or 14,1898 and mounted by George E. Atkinson (Atkinson, 1904). The last Manitoba sightings were both by Norman Criddle, then Manitoba's foremost naturalist, near the junction of the Souris with the Assiniboine: a spring migrant on April 8, 1899 and a male seen in the fall on September 21, 1902 (Macoun and Macoun, 1909). As it is only a sight record, the latter is not accepted as authentic, but depending on one's assessment of other contending sight records, it may have been the last Passenger Pigeon seen in the wild anywhere on this continent.

\section{Postscript: the Mourning Dove}

The final question for discussion is whether any of the sight records of socalled Passenger Pigeons may have involved mistaken identifications of Mourning Doves. In Saskatchewan, this is quite unlikely for a number of reasons. While all large flocks were almost certainly Passenger Pigeons, and while naturalists like Richardson, Drummond, King and Blakiston were unlikely to confuse the two species, the argument is strengthened most by the evidence that Mourning Doves seem to have been absent from Saskatchewan before the days of settlemes..t.

T. S. Roberts (1936) has described the increase of the Mourning Dove with settlement in northern Minnesota, appearing in many localities where it was formerly absent, as areas of forest were cleared for settlement. In 18821884, Ernest E. Thompson (later known as Ernest Thompson Seton) saw only one Mourning Dove in all his travels throughout Manitoba, and hence listed it as a rare summer resident (Thompson, 1890). In contrast, he reported on a return visit in 1892 (Thompson, 1893) that "on the Big Plain (north of Carberry), wherever there are trees and water, three or 
four pairs seem to be semi-domesticated around each barnyard."

The first Saskatchewan sighting of the Mourning Dove was apparently that of George F. Guernsey at Fort Qu'Appelle in 1880-1885 (Thompson, $1890)$. In 1892 , only a few stragglers were seen at Indian Head by Spreadborough (Macoun and Macoun, 1909), while by 1903, George Lang described it as common there. South of Calder, in the Yorkton area, R. P. Rooke noted the Mourning Dove only on rare occasions in the 1890's; the major increase in its numbers there did not occur until the period from 1925 or 1930 , through 1944 (Houston, 1949). Criddle and Atkinson reported to the Macouns (1909) that Mourning Doves became common along the Assiniboine and as far west as Yorkton, Saskatchewan, by 1906.

Mourning Doves were still rare at Quill Lake in 1909, with four observations in two months (Ferry, 1910) and at Davidson in 1932, with only four sightings in 10 weeks by a Carnegie Museum collecting expedition (Todd, 1947). Although Bent (1907) found them "very common in the timber along the creeks" in the Maple Creek area in 1905, Potter (1930) reported that at Eastend on the south side of the Cypress Hills, they had increased very noticeably since 1920 .

Mourning Doves were still a novelty in west-central Saskatchewan in 1931: Humphry (1932) reported one seen at the Manitoba Forest Reserve on August 20 and Bruggeman (1933) reported one 20 miles north and four miles east of Lloydminster on July 3; each was said to be a first record for the area.

\section{Conclusions}

It is evident that Passenger Pigeons migrated across the open plains of Saskatchewan in the days of the buffalo, but were resident in moderate numbers in wooded areas. We know they were once common near Cumberland House and on the south slopes of the Porcupine Hills in the Swan River valley, as well as at Winnipegosis and Grand Rapids in adjacent Manitoba.
They required wooded areas, and appear to have nested in moderate numbers there, whereas the open plains were unsuitable for Passenger Pigeons as well as for Mourning Doves. The Passenger Pigeon disappeared from Saskatchewan just as the settlers began to arrive.

With settlement, clearings were made in wooded areas and road allowances across the open plains made fire control possible. The clearings immediately provided suitable habitat for Mourning Doves, while fire control after a time allowed "bluffs" of poplar to grow up across the middle third of settled Saskatchewan. Such areas gradually became ideal habitat for the Mourning Dove, which reached approximately its present abundance only in the decade 1940-1950. To some extent, we may consider the Mourning Dove as filling the "niche" left by the disappearance of its once-abundant relative, the Passenger Pigeon. Meanwhile, another Columbiform, the Rock Dove, has been introduced by man and thrives by the thousands where human population is greatest-and this relatively new status of the Rock Dove has been essentially ignored and undocumented, much as the Passenger Pigeon was ignored when it was still abundant.

\section{LITERATURE CITED}

Atkinson, G. E. 1905. A review-history of the Passenger Pigeon of Manitoba. Trans. Hist. Sci. Soc. Manitoba, 68:7-8.

Atkinson, G. E. 1904. Rare bird records of Manitoba. Trans. Hist. Sci. Soc. Manitoba, $65: 8$.

Bell, C. N. 1928. The journal of Henry Kelsey, 1691-92. Trans. Hist. Sci. Soc. Manitoba, n.s., $4: 21$ and 24.

Bent, A. C. 1907. Summer birds of southwestern Saskatchewan. Auk, $24: 428$.

Blakiston, T. W. 1862-63. On birds collected and observed in the interior of British North America. Ibis, $4: 8$ and $5: 121$.

Bruggeman, P. F. 1933. Mourning Doves. Can. Field-Nat., 48:75.

Coubeaux, E. 1900. Contributions to the natural history of the Northwest Territories. Ottawa Naturalist, 14.27 .

Drummond, T. 1830. Sketch of a journey to the Rocky Mountains and to the Columbia River in North America. Botanical Miscellany, $1: 180-81$.

Ferry, J. F. 1910. Birds observed in Saskatchewan during the summer of 1909. Auk, $27: 198$. 
Franklin, J. 1823, Narrative of a journey to the shores of thhe Polar Sea, in the years $1819,20,21$ and 22. John Murray, London, pp. $185-86,670$ and 679 .

Harmon, D. W. 1820. A journal of voyages and travels in the interior of North America. Flagg and Gould, Andover, p. 91.

Hearne, S. 1795. A journey from Prince of Wales Fort in Hudson's Bay, to the Northern Ocean in $1769,1770,1771$ and 1772 . A. Strahan and T. Cadell, London, pp. 417-18.

Henry, A. (the younger). 1897. New light on the early history of the great North-west: the manuscript journals of Alexander Henry and of David Thompson. Edited by Elliott Coues. Francis P. Harper, New York, pp. 469 and 622 .

Hind, H. Y. 1860. Narrative of the Canadian Red River exploring expedition of 1857 , and of the Assiniboine and Saskatchewan exploring expedition of 1858. Longman, Green, Longman and Roberts, London. Vol. I, pp. 378 and 393.

Houston, C. S. 1949. The birds of the Yorkton district, Saskatchewan. Can. Field-Nat., 63 : 230 .

Houston, C. S, and M. G. Street. 1959. The birds of the Saskatchewan River, Carlton to Cumberland. Sask. Nat. Hist. Soc., Spec. Pub. 2, pp. 100-101.

Humphry, S. 1932. Mourning Doves. Can. Field-Nat., $46: 68$.

Kelsey, H. 1929. The Kelsey papers, with an introduction by A. G. Doughty and C. Martin. Public Archives of Canada, Ottawa, p. 7.

King, R. 1836. Narrative of a jounrey to the shores of the Arctic Ocean in 1833, 1834 and 1835. Richard Bentley, London, pp. 59 and 220.

Klaus, J. F. 1962. Fort Livingstone. Sask. History, $15: 93-110$.

Macoun, J. 1882. Manitoba and the great North-West. World Publishing Co., Guelph, p. 361 .

Macoun, J. 1922. Autobiography of John Macoun, M.A., Canadian explorer and naturalist. Ottawa Field-Naturalists Club, Ottawa, pp. 190-192.

Macoun, J., and J. M. Macoun. 1909. Catalogue of Canadian birds. Geological Survey Branch, Dept of Mines. Ottawa, pp. 235-38.

McDonald, A. 1872. Peace River. A canoe voyage from Hudson's Bay to the Pacific, by the late Sir George Simpson. Journal of the late chief factor, Archibald McDonald. Edited by Malcolm McLeod. J. Durie \& Son, Ottawa, p. 6.

Mellwraith, T. 1884. Birds of Ontario. William Briggs, Toronto.

Potter, L. B. 1930. Bird life changes in twentyfive years in southwestern Saskatchewan. Can. Field-Nat., $44: 148$.

Roberts, T. S. 1936. The birds of Minnesota. Uni. of Minnesota Press, Minneapolis, $p$. 574.

Schorger, A. W. 1955. The Passenger Pigeon. Univ. of Wisconsin Press, Madison, $424 \mathrm{pp}$.

Selwyn. A. R. C. 1875. Notes on a journey through the Northwest Territory, from Manitoba to Rocky Mountain House. Can. Naturalist Geologist, n.s., $7: 200$.

Smith, H. C., and R. S. Kidd. 1971. A record of the Passenger Pigeon in Alberta. Can. Field--Nat., $85: 259$.

Southesk [J. Carnegie], Ear] of, 1875. Saskatchewan and the Rocky Mountains. Edmonston and Douglas, Edinburgh, p. 58.

Swainson, W., and J. Richardson. 1832. Fauna Boreali-Americana, Vol. 2, The birds. John Murray, London, p. 363.

Thompson, E. E. 1886. The birds of western Manitoba. Auk., $3: 153$.

Thompson, E. E. 1890. The birds of Manitoba. Proc. U.S. Nat. Museum, $13: 522-23$.

Thompson, E. E. 1893. Additions to the list of Manitoba birds. Auk., 10:49.

Todd, W E. C. 1947. Notes on the birds of southern Saskatchewan. Annals Carnegie Museum, 30:404-05.

Whillans, J. W. 1955. First in the west-the story of Henry Kelsey. Applied Art Products, Edmonton, p. 75 .

\section{TWO NEW RECORDS OF THE VARIED THRUSH IN MANITOBA}

\section{by Norman Lee, R.R. 3, Selkirk, Manitoba}

About 6:30 p.m. on October 9, 1971, while I was watching a group of seven robins in my yard near Lockport, 23 miles north of Winnipeg, my attention was caught by one "Robin" which had a bright orange-red breast instead of the usual brick-red or washed out red. A closer look revealed a black band running across its breast. By then I was pretty sure that this was a Varied Thrush. I immediately went for The Birds of Canada by Earl Godfrey (1966) for an exact description.
Meanwhile my brother Jack watched the bird take a bath, then followed it to a crab-apple tree where it fed with robins on fallen crab-apples. He noted a thick orange-red eye line and two distinct orange wing bars on each wing and less noticeable orange lines along the primaries. The bird flew off following an alarmed robin and was not seen for the rest of the evening.

A search took place the next morning from $7: 30$ to $8: 30$ a.m. and again at 9:00 a.m. with Herb Copland. 